Maureen Junker-Kenny

"The Bold Arcs of Salvation History" 



\section{Maureen Junker-Kenny}

"The Bold Arcs of

Salvation History"

Faith and Reason in Jürgen Habermas's Reconstruction of the Roots of European Thinking 
ISBN 978-3-11-074629-7

e-ISBN (PDF) 978-3-11-074667-9

e-ISBN (EPUB) 978-3-11-074673-0

Library of Congress Control Number: 2021941797

Bibliographic information published by the Deutsche Nationalbibliothek

The Deutsche Nationalbibliothek lists this publication in the Deutsche Nationalbibliografie; Detailed bibliographic data are available in the Internet at http://dnb.dnb.de.

(c) 2022 Walter de Gruyter GmbH, Berlin/Boston

Cover illustration: Sta Maria di Pomposa; Photo: Corinne Poleij / iStock / Getty Images Plus Printing and binding: $\mathrm{CPI}$ books $\mathrm{GmbH}$, Leck

www.degruyter.com 
To Helmut and Ursula Peukert

In gratitude for their friendship

and for forty years of conversation on pursuits of agency

and in memory of Seán Freyne (1935-2013)

Historical Jesus Scholar

and Professor of Theology at Trinity College Dublin 1980-2002

for opening up the Scriptures to students and colleagues. 
